\title{
New and rare Rotifera from Thale-Noi Lake, Pattalang Province, Thailand, with a note on the taxonomy of Cephalodella (Notommatidae)
}

\author{
H. Segers ${ }^{1}$ \\ P. Pholpunthin ${ }^{2}$
}

Keywords : Rotifera, Thailand, taxonomy, biogeography.

The rotifer fauna present in Thale-Noi Lake, Pattalang Province, Thailand on the 16th September 1995 is reported. A total of 106 species, the majority of which belong to the genera Lecane $(31 \%)$, Lepadella $(13 \%)$ and Brachionus $(9 \%)$ are recorded. Cephalodella songkhlaensis n.sp. and Trichocerca siamensis n.sp. are described, Lecane calcaria Harring \& Myers is redescribed. An additional fourteen rotifer species are recorded for the first time from Thailand. The genera Metadiaschiza Fadeew and Paracephalodella Berzins are synonymized with Cephalodella Bory de St. Vincent.

Nouveaux et rares rotifères du Lac Thale-Noi, Pattaland Province, Thaïlande, avec une note sur la taxonomie de Cephalodella (Notommatidae)

Mots clés : Rotifères, Thaïlande, taxonomie, biogéographie.

Un bilan des rotifères présents le 16 septembre 1995 dans le lac Thale-Noi, Pattalang province, Thaillande, est donné. Un total de 106 espèces a été récolté, dont la majorité appartient aux genres Lecane (31\%), Lepadella (13\%) et Brachionus $(9 \%)$. Cephalodella songkhlaensis $n$.sp. et Trichocerca siamensis n.sp. sont décrites; Lecane calcaria Harring \& Myers est redecrite. Quatorze espèces sont nouvelles pour la Thaillande. Les genres Metadiaschiza Fadeew et Paracephalodella Berzins sont mis en synonymie avec Cephalodella Bory de St. Vincent.

\section{Introduction}

'Recently, several contributions dealing with the Thai rotifer fauna have been published (Segers \& Sanoamuang 1994, Sanoamuang et al. 1995). So far, the Thai rotifer record stood at 251 taxa (Sanoamuang et al. 1995). However, given that only a limited number of contributions have been made in this region, this number probably represents only a fraction of the real biodiversity of Thailand's freshwater Rotifera fauna. While studying the Rotifera of Thale-Noi Lake, we found several additions to the fauna, some of these even represent undescribed morphospecies. Here we

1. Laboratory of Animal Ecology, Zoogeography and Nature Conservation, Department M.S.E., University of Gent, K.L. Ledeganckstraat 35, B-9000 Gent, Belgium.

2. Department of Biology, Faculty of Science, Prince of Songkla University, Hat Yai 90112, Thailand. report on the Rotifera fauna of Thale-Noi Lake, redescribe one and describe two new morphospecies, and comment on the taxonomy of the genus Cephalodella.

\section{Material and methods}

Samples were collected in the littoral and pelagic zones of Thale-Noi Lake on 16th September 1995. The lake is situated in the uppermost of Songkhla Lake, between $7^{\circ} 45^{\prime}-55^{\prime} \mathrm{N}$ and $100^{\circ} 05^{\prime}-15 \mathrm{E}$, in the Southern part of Thailand. It covers an area of about 30 $\mathrm{km}^{2}$. The area is a protected bird sanctuary. Samples were collected using a $20 \mu \mathrm{m}$ plankton net, and immediately preserved in $4 \%$ formaldehyde solution. Animals were sorted under Wild M5 or Wild M10 dissection microscope, and examined and drawn using a Kyowa Medilux 12 compound microscope with camera lucida. Scanning electron microscopy (SEM) was performed with a JEOL JSM-840 microscope on trophi material processed following Segers (1993) and Segers \& Dumont (1993). 
All measurements reported here are in $\mu \mathrm{m}$. Types have been deposited in the Royal Belgian Institute for Natural Sciences, Brussels, Belgium (KBIN), the Academy of Natural Sciences, Philadelphia PA, USA (ANSP), in the collections of the Laboratory of Animal Ecology, University of Gent, Belgium (RUG), the department of Biology of the University of Antwerp, Belgium (RUCA), and the department of Biology, Prince of Songkhla University, Thailand (PSU).

\section{Results and discussion}

A total of 106 species, 17 of which are new to Thailand or new to science were identified (Table 1). Single specimens of apparently unnamed Colurella (Fig. 1) and Lecane (Fig. 2), were also found. These animals are not treated, here as the scarcity of material does not yet warrant complete descriptions. However, three of the rotifers found were collected in sufficient quantity to warrant taxonomic treatment.

\subsection{Family Lecanidae}

Lecane calcaria Harring \& Myers, 1926: Figs 3-6

non L. calcaria after Koste \& Böttger, 1992

\section{Diagnosis}

Lecane calcaria is an illoricate Lecane, distinguished from similar congeners such as $L$. clara by its large, projecting foot pseudosegment, and by the gradually tapering toes being remarkably wide proximally in lateral view. The occasional presence of a row of spicules dorsal to the foot plate supports the diagnosis. The taxon can be confused with $L$. hormemanni, but the latter has a distinct, though soft lorica, and, in lateral view, differently shaped toes. The large, sickle-shaped coxal plates, reported as diagnostic for the taxon by Harring \& Myers (1926), could not be seen in any of the material examined (see further).

\section{Description}

Parthenogenetic female: body illoricate. Outline of contracted animal anteriorly and laterally almost straight. Coxal plates indistict. A row of very small spicules occasionally present dorsally of the foot plate. Transverse fold mostly present, irregular. Prepedal fold elongate, with median projection. Foot pseudosegment large, laterally constricted and projecting. Toes gradually tapering, proximally relatively broad in lateral view. Male unknown. Measurements: see table 2.

Distribution and comments

L. calcaria was described from a pond near Oceanville, Atlantic county, New Jersey, USA. The collection of ANSP contains two slides of $L$. calcaria, one with three specimens from the type locality (ANSP 799) and one with four animals from another pond in. Atlantic county (Gravelly run, ANSP 628). Although the first-mentioned specimens are not labeled as type specimens, it is likely that they do belong to the type series or, at the least, originate from the same sample: the indicated collection date is August, 1,1920, whereas the original description, published 1926, states that «Lecane calcaria was collected in large numbers in a swamp at Oceanville, near Atlantic City, New Jersey, some four years ago; it has not occurred elsewhere». No originally designated type is known to exist of the species. There is an important discordance between the description and, especially, drawings of Harring \& Myers (1926), and the study material. That our material does belong to $L$. calcaria could only be concluded from the examination of the above-mentioned material in ANSP. The figure 6 represents one of the presumed syntypes. Similar observations were made regarding a few other rotifers described by Harring \& Myers (1926).

Table 2. Measurements on Lecane calcaria Harring \& Myers, 1926.

Tableau 2. Dimensions de Lecane calcaria Harring \& Myers, 1926.

\begin{tabular}{lccccc}
\hline & Thai & Thai & $\begin{array}{c}\text { Nigeria } \\
\text { (Segers et al. 1993) }\end{array}$ & $\begin{array}{c}\text { Madagascar } \\
\text { (Segers 1992) }\end{array}$ & $\begin{array}{c}\text { U.S.A. }{ }^{2} \\
\text { (Harring \& Myers 1926) }\end{array}$ \\
\hline lorica length & 1 & 2 & 51 & $(74)^{1}$ & $49-50$ \\
lorica width & 54 & 51 & 52 & 9 & $38-41$ \\
foot pseudosegment length & 44 & 46 & 15 & 9 & $9-10$ \\
foot pseudosegment width & 10 & 12 & 9 & 20 & $15-17$ \\
toe length & 9 & 9 & 19 & 95 & \\
\hline
\end{tabular}

1: incompletely contracted specimens; 2 : including new measurements 
Table 1. List of the Rotifera from Thale-Noi Lake (*: New to Thailand).

Tableau 1. Liste des Rotiferes du lac Thale-Noi (*: Nouvelle pour la Thailande).

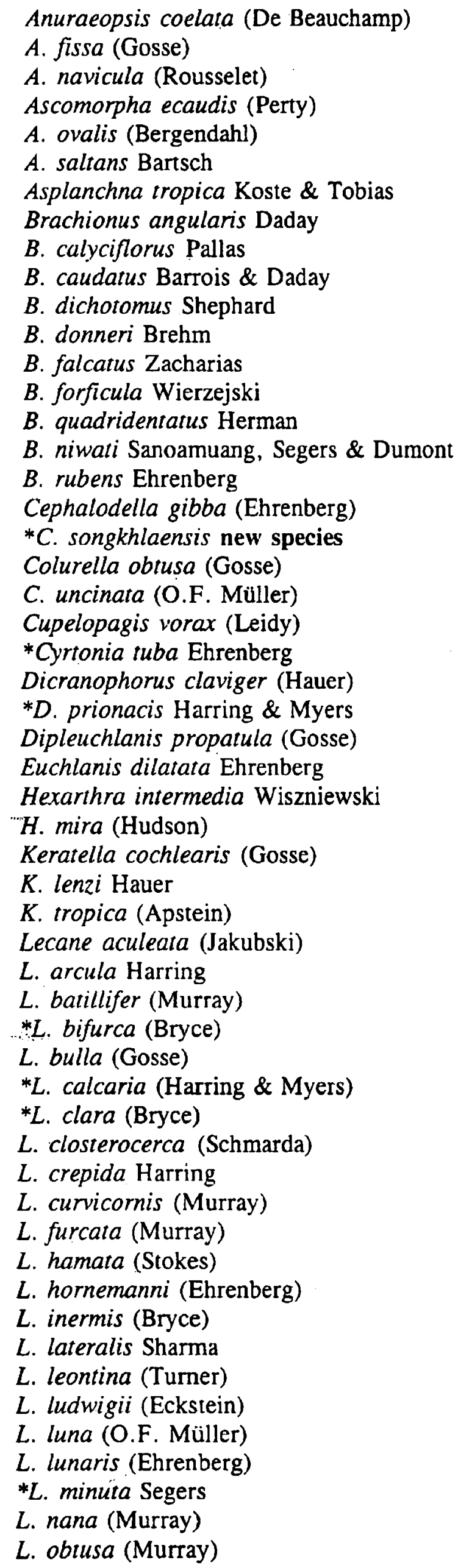

L. papuana (Murray)

*L. pertica Harring \& Myers

L. quadridentata (Ehrenberg)

L. rhenana Hauer

${ }^{*}$ L. rhytida Harring \& Myers

L. signifera (Jennings)

${ }^{*} L$. sympoda Hauer

L. tenuiseta Harring

L. undulata Hauer

L. unguitata (Fadeew)

L. ungulata (Gosse)

Lepadella apsicora Myers

L. apsida Harring

L. biloba (Hauer)

L. dactyliseta Stenroos

${ }^{*} L$. heterostyla Murray

L. latusinus (Hilgendorf)

${ }^{*} L$. lindaui Koste

${ }^{*}$ L. minoruoides Koste \& Robertson

L. ovalis (O.F. Müller)

L. patella (O.F. Müller)

L. quadricarinata Stenroos

L. rhomboides (Gosse)

L. vandenbrandei Gillard

L. triba Myers

Macrochaetus sericus (Thorpe)

*Monommata actices Myers

Mytilina compressa (Gosse)

Notommata copeus Ehrenberg

${ }^{*} N$. pseudocerberus De Beauchamp

Plationus patulus (O.F. Müller)

Platyias quadricornis (Ehrenberg)

Polyarthra minor Voigt

$P$. remata (Skorikov)

$P$. vulgaris Carlin

Scaridium bostjani Daems \& Dumont

S. longicaudum (O.F. Müller)

Squatinella lamellaris (O.F. Müller)

Testudinella brevicaudata Yamamoto

T. patina (Hermann)

*T. walkeri Koste \& Shiel

Trichocerca cylindrica (Imhof)

$T$. dixonnutalli Jennings

T. flagellata Hauer

T. hollaerti De Smet

T. insignis (Herrick)

T. relicta Donner

$T$. ruttmeri Donner

${ }^{*} T$. siamensis new species

$T$. similis (Wierzejski)

$T$. tropis Hauer

Trichotria tetractis (Ehrenberg) 


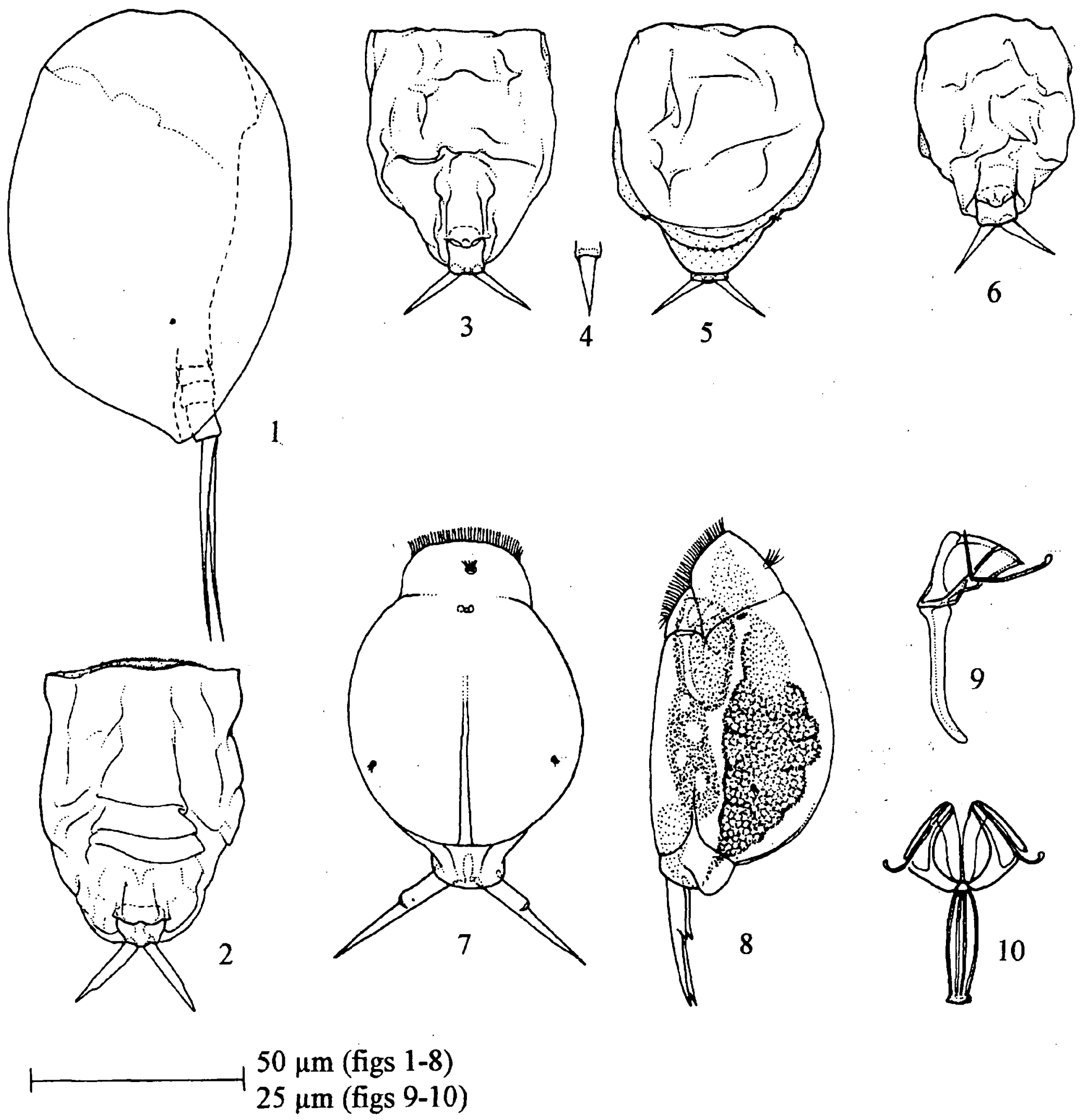

Fig. 1. Colurella species, lateral; Fig. 2: Lecane species, ventral.

Figs 3-6. Lecane calcaria Harring \& Myers, 1926. 3, 6. ventral views, 4. toe, lateral view, 5. dorsal view (6. syntype, in ANSP). Figs 7-10. Cephalodella songkhlaensis $\mathrm{n} . \mathrm{sp}$. 7, 8. habitus, 9-10. trophi; 7, 10. dorsal view, 8, 9. lateral view.

Fig. 1. Colurella espèce, vue laterale; Fig. 2. Lecane espèce, vue ventrale.

Figs 3-6. Lecane calcaria Harring \& Myers, 1926. 3, 6. vues ventrales, 4. orteil, vue laterale, 5. vue dorsale (6. syntype, in ANSP) Figs 7-10. Cephalodella songkhlaensis n.sp. 7, 8. habitus, 9-10. trophi; 7, 10. dorsal view, 8, 9. vue laterale. 
In addition to the Thai material, single specimens of L. calcaria were encountered in a sample from Madagascar (Sample 2: see Segers 1992) and Nigeria (IyiEfi Lake: see figure 4 in Segers et al. 1993). In both cases, the animals had not been fully identified. The record of this species from Ecuador by Koste \& Böttger (1992) probably concerns a different taxon. Considering that $L$. calcaria occurs on several continents, and that only the New Jersey record is from temperate latitudes, the taxon may be tropicopolitan.

\subsection{Family Notommatidae}

\section{Cephalodella songkhlaensis n.sp.: Figs 7-15}

Material examined: Holotype and one paratype in KBIN (IG 28334 RIR 67, 68), one paratype in ANSP (1010), RUCA and PSU each, two paratypes in RUG; one SEM trophi preparation containing three trophi in RUG. More specimens were present in the original samples (in PSU) from the type locality, Thale-Noi Lake, Pattalang province, Thailand.

\section{Differential diagnosis}

By the presence of small cervical eyes sharing the same lens, the peculiar shape of the toes, and the A-type trophi, Cephalodella songkhlaensis n.sp. can hardly be confused with any congener. The shape of its toes is reminiscent of Cephalodella stenroosi Wulfert, but the latter species has different trophi (D-type). The shape of the trophi, especially the presence of a wide fulcrum, probably indicates that the taxon is a close relative of Cephalodella plicata Myers and the poorly described Paracephalodella latifulcrum Berzins. However, its different toe shape easily distinguishes $C$. songkhlaensis n.sp.

\section{Description}

Parthenogenetic female (preserved specimens): Body slightly elongated, bulbous, slightly less than three times as long as toes. Lorica flexible. Corona oblique, slightly convex. Tail short, broad, reaching beyond the foot. Foot in body axis. Double cervical, red-pigmented eyes present. A single, small lens. Inner organization obscured by presence of zoochlorellae. Vitellarium with four nuclei. Toes slightly dorsally bent, smoothly tapering to acute distal point. A dorsal, posteriorly rounded lump present. Trophi type A. Fulcrum recurved and spatulate distally, wide in ventral view. Four rod-shaped ridges on fulcrum present. Rami rounded triangular in ventral view. Basal apophysis elongate, rounded distally, the right fenestrated. A pair of rod-shaped accessory trophi parts, concealed by the rami present. Unci slender, acutely pointed. Manubria rod-shaped, dorsally curved. No epipharynx. Male unknown.

\section{Measurements}

Total length 113-117, toes 31-34, trophi 24-26 (fulcrum 15-17, manubrium 9).

\section{Distribution}

Cephalodella songkhlaensis n.sp. is so far known from its type locality, Thale-Noi Lake, only.

\section{Etymology}

The name songkhlaensis is a toponym, derived from the name of Songkhla Lake.

\section{Comment}

Describing soft-loricate Rotifera obtained from preserved material is infrequently done, considering that such are normally contracted to an unrecognizable state. In this case, however, we ventured to describe the animal notwithstanding the fact that we were unable to examine living animals. Fortunately, many of the specimens were only slightly contracted, with their corona still extended. Also, diagnostic features of the morphospecies are such, that the taxon is unmistakable. It is likely, though, that the body of living animals is more elongate than is reported here.

C. songkhlaensis n.sp. shares its wide fulcrum with C. plicata Myers, 1924 (see Koch-Althaus 1963) and, especially, Paracephalodella latifulcrum Berzins, 1976. This probably reflects close phylogenetic relations between the taxa. The validity of the monospecific genus Paracephalodella Berzins had already been questioned because of the dubiousness of the criteria making up its diagnosis (W. Koste in Nogrady et al. 1995). Koste (1978) considers it as a subgenus of $\mathrm{Ce}$ phalodella. This doubt is further stressed by the apparently close taxonomic relationship between $C$. songkhlaensis n.sp., C. plicata and P. latifulcrum.

The validity of a second monospecific genus closely related to Cephalodella, Metadiaschiza Fadeew (incorrectly ascribed to Rousselet by Nogrady et al. 1995) is also questionable. The single feature diagnosing the latter genus from Cephalodella is that its lorica is heavy and granulated. The lorica structure, however, consisting of a midventral and a pair of dorso-lateral plates, is identical (e.g., compare Metadiaschiza trigona (Rousselet) with Cephalodella plicata, concerning lorica cross-section). Lorica stiffness is a variable character. This holds not only for Cephalodella, but also for several other rotifer genera containing both heavily loricated and illoricated taxa (e.g., Ascomorpha Perty and Lecane Nitzsch, to name a few). As mentioned by Nogrady et al. (1995), all other features of the morphospecies agree closely to Cephalodella. 

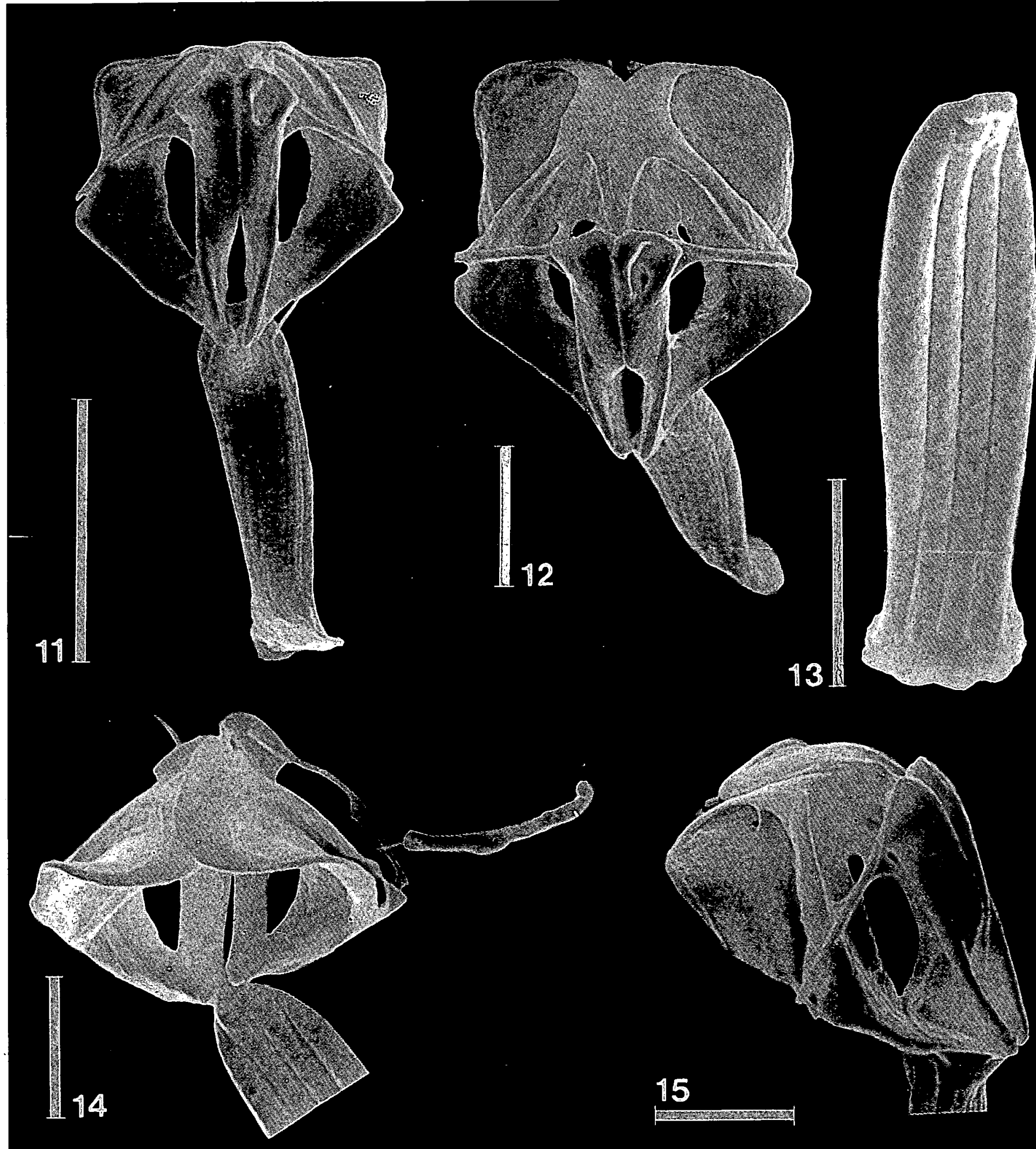

Figs 11-15. Cephalodella songkhlaensis n.sp., trophi SEM photographs. 11. ventral view, 12. frontal view, 13. fulcrum, dorsal view, 14. rami, dorsal view, 15. rami, lateral view.

Figs 11-15. Cephalodella songkhlaensis n.sp., trophi MEB photographies. 11. vue ventrale, 12. vue frontale, 13. fulcrum, vue dorsale, 14. rami, vue dorsale, 15. rami, vue latérale. 
It could be argued that the distinction of separate genera could be helpful in dealing with a genus like $\mathrm{Ce}$ phalodella, containing a large number (over 190, see Nogrady et al. 1995) of morphospecies. However, this is hardly relevant in this case, as both Paracephalodel$l a$ and Metadiaschiza are monospecific. So, because of the taxonomic irrelevance of their diagnostic features, we hereby synonymize the genera Paracephalodella Berzins, 1.976 (monotype: P. latifulcrum Berzins, 1976) and Metadiaschiza Fadeew, 1925 (type: M. trigona (Rousselet, 1895)) with Cephalodella Bory de St. Vincent, 1826, and relocate their constituent nominal taxa to the latter genus (Cephalodella latifulcrum (Berzins) n.comb., C. trigona (Rousselet) n. comb., with as junior subjective synonyms: $C$. sculpturata (Daday) n.comb. and C. leptodactyla (Hauer, 1922 ; Harring \& Myers, 1924).

\subsection{Family Trichocercidae}

\section{Trichocerca siamensis n.sp.: Figs 16-22}

\section{Material examined}

Holotype and one paratype in KBIN (IG 28331 RIR 70, 71), one paratype in ANSP (1011), RUG and PSU, each. More specimens from the type locality, ThaleNoi Lake, were examined. Several specimens in samples collected in January 1996 in Broa reservoir, Itirapira, São Carlos, SP., Brazil.

\section{Differential diagnosis}

The external morphology of Trichocerca siamensis is strikingly similar to T. uncinata (Voigt, 1902); however, the two are easily distinguished by their trophi morphology. The asymmetry of the trophi is much less expressed in $T$. siamensis $n$.sp. than in $T$. uncinata, whereby differences in shape of left uncus and alulus, and right manubrium are especially noticeable. It is probable that the two have been confused in the past.

\section{Description}

Parthenogenetic female: lorica stout, head aperture with strongly elongate, acutely pointed and weakly curved spine right-dorsally. Remaining part of head aperture with parallel folds. An elongate antero-dorsal longitudinal ridge weakly developed, running along about one fourth of lorica. Apertures to lateral antennas more or less at same level, in posterior third of body. Foot conical, inserted subdistally and ventrally. Toes equal in length, the left with broad basis. Substyli present.

Trophi moderately asymmetrical. Fulcrum elongate, basal plate and ventral crest well-developed. Right ramus with four-toothed suprauncus, alulus proximally at $45^{\circ}$ inclination from main axis, distally at $90^{\circ}$, cur- ved dorsally in lateral view. Alulus of left ramus at $45^{\circ}$. Suprarami present. Right manubrium elongate, L-shaped, with a weak triangular projection dorsal and distally. This projection dissolves quickly in $\mathrm{NaOCl}$. Left manubrium rod-shaped, curved distally, only slightly shorter but much slender than right manubrium. Right uncus consisting of single basal element and fan-shaped distal element consisting of three fused teeth. Left uncus consisting of two separate rod-shaped elements.

Male unknown.

Measurements (of Thai and Brazilian specimens, measurements of the two populations overlap largely): total length (without anterior spine): 61-69:, body height 44-46, width 40 , anterior spine length $11-16$, toe length 17-21, trophi length 24-25 (fulcrum 19-20, left manubrium $18-19$, right manubrium 17 , rami width 13).

\section{Etymology}

The name siamensis is a toponym. It is derived from Siam, the former name of the country where the species was found first.

\section{Distribution and ecology}

As already mentioned, $T$. siamensis n.sp. may have been confused with $T$. uncinata, which is a cold-water species. The record of $T$. uncinata from Katanga, Zaire by Gillard (1952) may concern T. siamensis n.sp. Probably, $T$. siamensis $n$.sp. is an even more widespread species. It occurred in the plankton of the littoral zone in both localities, but it was also found in the psammon, in Broa reservoir.

\subsection{Species composition of the rotifer fauna of Tha- le-Noi Lake}

Tje majority of the 106 rotifer taxa identified from Thale-Noi Lake (Table 1) belongs to the genera Lecane (31\%), Lepadella (13\%) and Brachionus (9 \%). These proportions are fairly similar to previous reports (e.g., Segers et al., 1993), especially regarding the high proportion of littoral Lecane rotifers. A predominance of these animals in tropical soft waters is well documented (see Dussart et al. 1984). The vast majority of Rotifera in Thale-Noi Lake is widely distributed. Some of the taxa recorded from Thailand for the first time even belong to this category. Examples are Lepadella heterostyla (Fig. 23) and L. lindaui (Figs 24-25). Some of the widely distributed taxa are restricted to tropical regions, e.g., Lepadella minoruoides, the record of which is the first from Asia. Trichocerca siamensis n.sp. may also be a pantropical species.

Seven of the Rotifera found $(6.6 \%)$ are restricted to the Old World. These are Asplanchna tropica, Bra- 

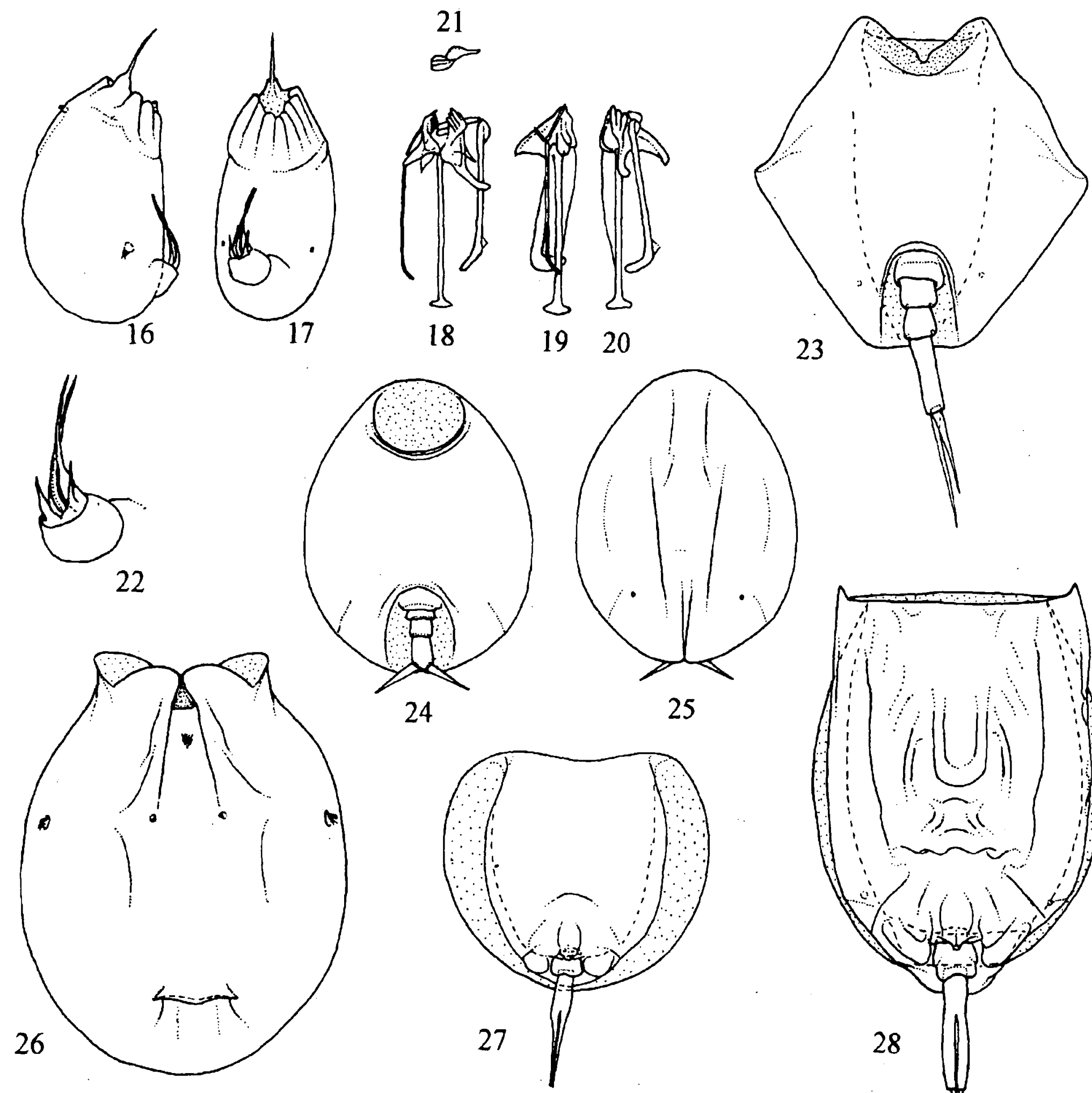

24

$50 \mu \mathrm{m}$ (figs $16,17,23-28)$

$25 \mu \mathrm{m}$ (figs 18-22)

Figs 16-22. Trichocerca siamensis $\mathrm{n} . \mathrm{sp} .16,17$. habitus, 18-20. trophi, 21 . uncus, 22. foot. 16, 19, 20. lateral view, 17, 18, 22. ventral view. Fig. 23. Lepadella heterostyla Murray, ventral; Figs. 24-25. L. lindaui Koste, ventral, dorsal; Fig. 26. Testudinella walkeri Koste \& Shiel, dorsal; Fig. 27. Lecane minuta Segers, ventral; Fig. 28. L. sympoda Hauer, ventral.

Figs 16-22. Trichocerca siamensis n.sp. 16, 17. habitus, 18-20. trophi, 21. uncus, 22. pied. 16, 19, 20. vue latérale, 17, 18, 22. vue ventrale. Fig. 23. Lepadella heterostyla Murray, ventrale; Figs 24-25. L. lindaui Koste, ventrale, dorsale; Fig. 26. Testudinella walkeri Koste \& Shiel, dorsale; Fig. 27. Lecane minuta Segers, ventrale; Fig. 28. L. sympoda Hauer, ventrale. 
chionus forficula, Lecane lateralis, L. sympoda (Fig. 28), L. unguitata, Lepadella vandenbrandei and Testudinella brevicaudata. Brachionus dichotomus, Lecane batillifer, and Testudinella walkeri (Fig. 26) are Australasian $(2.8 \%)$. Brachionus donneri, B. niwati, Cephalodella songkhlaensis n.sp., and Lecane minuta (Fig. 27) are Oriental endemics (3.8\%). It is not known whether or not the proportions noted here are real, or an artifact of our incomplete knowledge. This is exemplified by the distribution of the taxa treated in the taxonomy section of this paper, and by the fact that quite a few rotifers recorded here have been encountered on few occasions only (e.g., Lecane minuta and Testudinella walkeri: second record; Lecane sympoda, Lepadella lindaui). The presence of two probably undescribed taxa (single specimens) also supports this conclusion.

\section{Acknowledgments}

This contribution is a result of the International Training Course on 'Freshwater Zooplankton, a tool in Lake Management', sponsored by BADC (Belgium). Part of this study was performed while H.S. was a post-doctoral research fellow at the Academy of Natural Sciences of Philadelphia (John J. and Anna H. Gallagher fellowship).

\section{References}

Dussart C.H. Fernando C.H., Matsumura-Tundisi T. \& Shiel R.J. 1984. - A review of systematics, distribution and ecology of tropical freshwater zooplankton. Hydrobiologia, 113: 77-91.
Gillard A. 1952. - Rädertiere von Katanga. Medd. Landbouww. hogesch. Gent, lemeded., 17: 333-352.

Harring H.K. \& Myers F.J. 1926. - The rotifer fauna of Wisconsin. III. A revision of the genera Lecane and Monostyla. Trans. Wisconsin Acad. Sci., Arts and Letters, 22:315-423.

Koch-Althaus B. 1963. - Systematische und ökologische Studien an Rotatorien des Stechlinsees. Limnologica (Berlin) 1: 375-456.

Koste W. 1978. - Rotatoria. Die Rädertiere Mitteleuropas. Bornträger, Berlin, 2 Vols: 673p., 234 plates.

Koste W. \& Bîttger K. 1992. - Rotatorien aus Gewässern Ecuadors II. Amazoniana, 12: 263-303.

Nogrady T., Pourriot R. \& Segers H. 1995. - Rotifera 3: The Notommatidae and the Scarididae. Guides to the Identification of the Microinvertebrates of the Continental Waters of the World 8, T. Nogrady \& H.J. Dumont eds., SPB Academic Publishing bv. The Hague, The Netherlands, 248 p.

Sanoamuang L., Segers H. \& Dumont H.J. 1995. - Additions to the rotifer fauna of Thailand, with the description of a new species. Hydrobiologia, 313/314: 34-45.

Segers H. 1992. - Taxonomy and zoogeography of the rotifer fauna of Madagascar and the Comoros. J. Afr. Zool., 106: 351-361.

Segers H. 1993. - Rotifera of some lakes in the floodplain of the River Niger (Imo State, Nigeria). I. New species and other taxonomic considerations. Hydrobiologia, 250:39-61.

Segers H. \& Dumont H.J 1993. - Rotifera from Arabia, with descriptions of two new species. Fauna of Saudi Arabia, 13: 3-26.

Segers H. \& Sanoamuang L. 1994. - Two more new species of $L e$ cane (Rotifera, Monogononta), from Thailand. Belg. J. Zool., 124: 39-46.

Segers H., Nwadiaro C.S. \& Dumont H.J. 1993. - Rotifera of some lakes in the floodplain of the River Niger (Imo State, Nigeria). II. Faunal composition and diversity. Hydrobiologia, 250: 113-121. 